\title{
Spectral study of thione-thiol tautomerization of thiourea in aqueous alcohol solution
}

\begin{abstract}
In this work we studied the equilibrium of thione-thiol tautomerization by Raman and UV spectroscopies. This type of tautomerization influences on the course and direction of the reaction between thiourea and other organic compounds. The studies were carried out in water and aqueous alcohol medium. Methanol, ethanol, propanol-1 and propanol-2 were used as alcohols. Hydrochloric acid was used to protonate thiourea in water and aqueous alcoholic solutions. UV spectroscopy made it possible to establish the tautomer ratio in water and aqueous alcohol solutions as the ratio of the intensities of absorption bands at 236 and $200 \mathrm{~nm}$. There is an increase in the content of the thiol form and a decrease of the thione form observed in the row watermethanol-ethanol-propanol-isopropyl alcohol. The addition of hydrochloric acid to the thiourea water or aqueous alcohol solutions leads to the increase of the thione form and to the decrease of the thiol form in the composition. The thione form of thiourea can be determine by Raman spectra of $-\mathrm{C}=\mathrm{S}$ group. The thiol form of thiourea is difficult to detect by Raman spectroscopy due to the overlap of the $-\mathrm{S}-\mathrm{H}$ bond absorption band with alcohols absorption bands.
\end{abstract}

Keywords: thiourea, thione-thiol tautomerization, Raman-spectroscopy, UV-spectroscopy, autoprotolysis constant, protonation of thiourea, solvent effects.

\section{Introduction}

Thiourea is one of the common reagents to synthesize sulfur-containing heterocyclic compounds. These compounds are used in medicine to produce thiobarbituric acid and sulfathiazolum [1], as a corrosion inhibitor for metals [2], a ligand in chemosensors for transition and rare earth metals [3], etc.

Thiourea has a planar $\left(\mathrm{N}_{2} \mathrm{CS}\right)$ core; its molecule consists of electron-withdrawing $-\mathrm{C}=\mathrm{S}$ and electrondonating $\mathrm{NH}_{2}$ groups; thus, there is an equilibrium between the thione (1) and thiol (2) forms in solution (Fig. 1).<smiles>CCC(N)=S</smiles>

(1)<smiles>N=C(N)S</smiles>

(2)

Figure 1. Thiourea thione-thiol tautomerization

The equilibrium of thione-thiol tautomerization depends on many factors, but the $\mathrm{pH}$ and type of solvent are the most significant. This type of tautomerization influences on the chemical reaction progress and directions as shown in [4] on the example of the thiourea reaction with glyoxal to obtain 4,5-dihydroxyimidazolidin-2-thione or tetrahydrothiazolo[5,4-d]thiazole-2,5-diimine. Thus, it is important to identify which thiourea form predominates in solution under different conditions in order to understand the chemistry of the formation of sulfur-containing heterocycles.

The effect of $\mathrm{pH}$ on the thione-thiol equilibrium in thiourea aqueous solutions was studied using NMR, HPLC-MS, GC-MS, IR, UV and Raman spectroscopy [4-8]. The influence of methanol, dioxane, and acetonitrile on this equilibrium was studied in Ref. [3]. However, there was no systematic study of thione-thiol tautomerization of thiourea in aqueous alcohol solution.

UV spectroscopy is one of the simplest and most informative methods to investigate the thione-thiol tautomerization. It allows to establish the tautomer ratio in the solutions. A combination of UV and Raman spectroscopy makes it possible to define the isomeric forms of thiourea more precisely.

\footnotetext{
${ }^{*}$ Corresponding author
} 
Based on the above, the aim of this work is to investigate the thione-thiol tautomerization of thiourea in aqueous alcohol solution by Raman and UV spectroscopies.

\section{Experimental}

Water was purified using a Milli-Q purification system (Merck Millipore, USA). All reagents and chemicals used were of analytical grade. Methanol (99.9\%), Ethanol (99.9 \%), Propanol-1, Propanol-2, thiourea $(99+\%)$ were purchased from Acros Organics (USA) and $35 \%$ hydrochloric acid was purchased from Ecos-1 (Russia).

The UV- experiments were carried out using a Shimadzu UV-1800 (Shimadzu, Japan). The spectral data was collected in the range from 200 to $300 \mathrm{~nm}$. Solutions of thiourea in water or water/alcohol $60 / 40 \mathrm{vol}$. \% with $0.042 \mathrm{mg} / \mathrm{ml}$ thiourea concentration were used for UV experiments. Protonation of thiourea were carried out by addition of hydrochloric acid to $\mathrm{pH}=2$.

Raman spectra were obtained by using iHR SP320 Raman spectrometer from Horiba Scientific. $2 \%$-Solutions of thiourea in water or water/alcohol 60/40 vol. \% were used for Raman experiments.

\section{Results and Discussion}

Firstly, the aqueous alcohol solutions of thiourea were investigated by UV spectroscopy. The UV spectra of the thiourea solution in water have two absorption maxima at $200 \mathrm{~nm}$ and $236 \mathrm{~nm}$ as shown in Figure 2 .

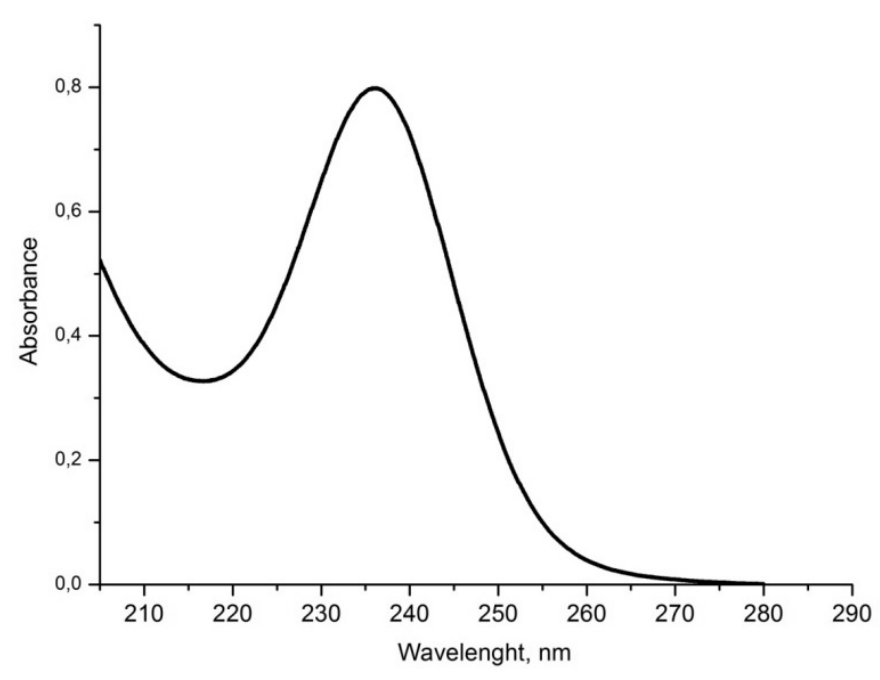

Figure 2. UV spectra of the thiourea solution in water

Absorption at $200 \mathrm{~nm}$ is due to the charge transfer between two amino groups, which is characterized by the resonance structure (Fig. 3) and refers to the protonated form of thiourea. Absorption at $236 \mathrm{~nm}$ relates to electronic transitions in the $-\mathrm{C}=\mathrm{S}$ bond [9]. Thus, the first and second maxima are responsible to the presence of thiol form 2 and thione form 1 , respectively.

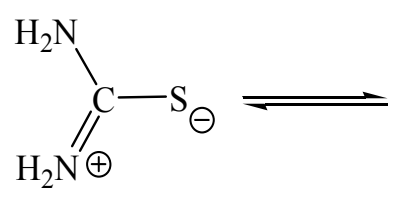<smiles>NC(=[NH2+])[O-]</smiles>

Figure 3. Charge transfer between two amino groups of thiourea

The ratio of the absorbance at 236 and $200 \mathrm{~nm}$ (A236/A200) was used to assess the change in the ratio of isomers.

Water is a stronger acid than alcohols; therefore, protonation of thiourea by water is easier. As a result, the use of water as a solvent instead of aqueous alcohol medium leads an increase of the thiol form and a decrease of the thione form in the composition, respectively (Table 1). 
Alcohols are weaker acids compared to water due to the presence of an alkyl substituent having a positive inductive effect, which increases the electron density on the oxygen atom and, therefore, reduces the polarity of the $\mathrm{O}-\mathrm{H}$ bond.

The acidity of alcohols decreases from methanol to propanol, therefore, the amount of the thione form of thiourea increases in the solution.

T a ble 1

Absorption maxima of thiourea in the water and aqueous alcohol solutions

\begin{tabular}{|c|c|c|c|c|c|c|c|}
\hline Solvent & $\begin{array}{c}\text { Dielec- } \\
\text { tric con- } \\
\text { stant of } \\
\text { solvent, } \\
\varepsilon\end{array}$ & $\begin{array}{c}\text { Absorbance at } \\
200 \text { nm }\left(\mathbf{A}_{1}\right) \\
\text { without } \\
\text { hydrochloric } \\
\text { acid }\end{array}$ & $\begin{array}{l}\text { Absorbance at } \\
236 \mathrm{~nm}\left(\mathbf{A}_{2}\right) \\
\text { without } \\
\text { hydrochloric } \\
\text { acid }\end{array}$ & $\begin{array}{c}\text { Absorbance at } \\
200 \text { nm }\left(\mathbf{A}_{3}\right) \\
\text { with } \\
\text { hydrochloric } \\
\text { acid }\end{array}$ & $\begin{array}{l}\text { Absorbance at } \\
236 \mathrm{~nm}\left(\mathbf{A}_{4}\right) \\
\text { with } \\
\text { hydrochloric } \\
\text { acid }\end{array}$ & $\mathbf{A}_{2} / \mathbf{A}_{1}$ & $\mathbf{A}_{3} / \mathbf{A}_{4}$ \\
\hline Water & 81 & 0,54 & 0,75 & 0,55 & 0,8 & 1,55 & 1,45 \\
\hline $\begin{array}{l}\text { Water/methanol } \\
60 / 40 \text { vol. } \%\end{array}$ & 33,1 & 0,58 & 0,72 & 0,57 & 0,83 & 1,24 & 1,42 \\
\hline $\begin{array}{l}\text { Water/ethanol } \\
60 / 40 \text { vol. } \%\end{array}$ & 24,3 & 0,46 & 0,79 & 0,57 & 0,84 & 1,72 & 1,40 \\
\hline $\begin{array}{l}\text { Water/propanol-1 } \\
60 / 40 \text { vol. } \%\end{array}$ & 21,8 & 0,38 & 0,92 & 0,57 & 0,79 & 2,42 & 1,39 \\
\hline $\begin{array}{l}\text { Water/propanol- } 2 \\
60 / 40 \text { vol. } \%\end{array}$ & 18,3 & 0,38 & 0,9 & 1,2 & 0,63 & 2,37 & 0,53 \\
\hline
\end{tabular}

Comparison of the obtained results with reference data on the dielectric constant of solvents (Fig. 4) shows that when the dielectric constant of solvents is increased, the amount of thione form is increased, and the amount of thiol form is decreased. These facts are consistent Ref. [5].

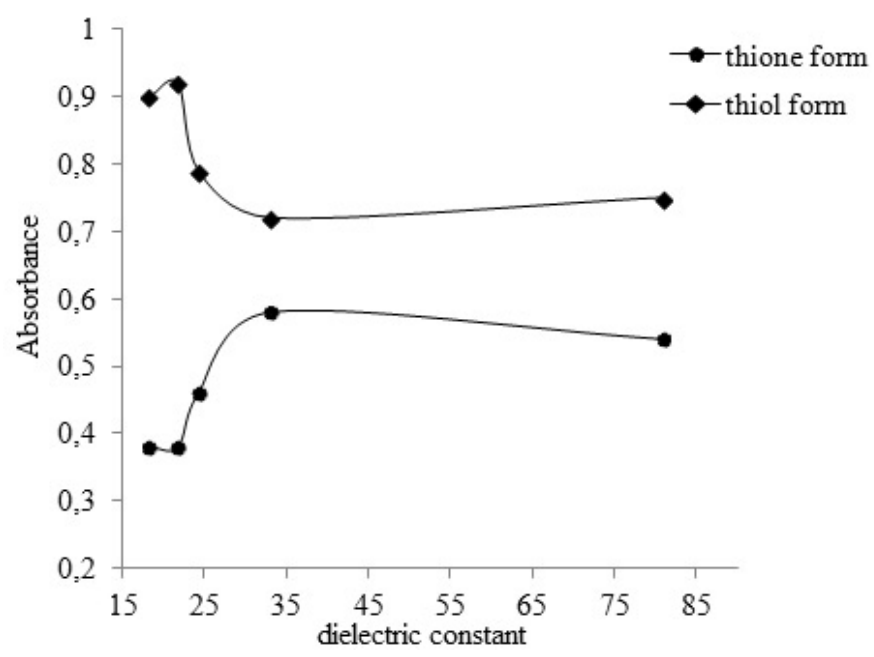

Figure 4. Dependence of thione-thiol forms on dielectric constant of solvents

The addition of hydrochloric acid to the thiourea water or water/alcohols solutions causes an increase of thione form content and a decrease of thiol form content of thiourea. This is due to the decreases of the solvent autoprotolysis constant, and to the easier protonation of thiourea as a stronger base in alcohols.

The equilibrium between the tautomeric forms of thiourea was studied by Raman spectroscopy since the thione group has a characteristic intense band corresponding to stretching vibrations of $-\mathrm{C}=\mathrm{S}$ in the region of $732 \mathrm{~cm}^{-1}$ [10-12]. It is difficult to detect an absorption band with a low intensity in the region of $2800 \mathrm{~cm}^{-1}$ for the S-H bond (corresponding to the thiol form of thiourea) due to its overlap with the solvent bands. The absorption band in the region of $481 \mathrm{~cm}^{-1}$ (corresponding to the stretching vibrations of the $-\mathrm{C}-\mathrm{N}-\mathrm{C}$ fragment) is overlapped by the absorption bands of propyl and isopropyl alcohols. In view of the above, the effect of the alcohols only on the thione form of thiourea was considered. 
The absorption band of the thiourea $-\mathrm{C}=\mathrm{S}$ group in water/alcohol solutions shifts to a long wave region compared to the same band in water (Table 2). This fact is explained in Ref. [7, 10-12] by the predominance of the thione form of thiourea in solutions.

The maximum shift of the studied band is observed in isopropyl alcohol, which may be due to the steric effects and a more specific interaction of thiourea and isopropyl alcohol.

Ta a le 2

Raman bond thione group in the water and aqueous alcohol solutions

\begin{tabular}{|c|c|c|c|c|}
\hline $\begin{array}{c}-\mathrm{C}=\mathrm{S} \text { band } \\
\text { in water, } \mathrm{cm}^{-1}\end{array}$ & $\begin{array}{c}-\mathrm{C}=\mathrm{S} \text { band } \\
\text { in methanol, } \mathrm{cm}^{-1}\end{array}$ & $\begin{array}{c}-\mathrm{C}=\mathrm{S} \text { band } \\
\text { in ethanol, } \mathrm{cm}^{-1}\end{array}$ & $\begin{array}{c}-\mathrm{C}=\mathrm{S} \text { band } \\
\text { in propanol-1, } \mathrm{cm}^{-1}\end{array}$ & $\begin{array}{c}-\mathrm{C}=\mathrm{S} \text { band } \\
\text { in propanol-2, } \mathrm{cm}^{-1}\end{array}$ \\
\hline 731 & 738 & 737 & 737 & 743 \\
\hline
\end{tabular}

In addition, the intensity of the Raman band of the thione group is decreased with increasing of the solvent dielectric constant. This also indicates the screening of this group due to the solvation by alcohols [12]. The experimental data obtained by Raman spectroscopy are consistent with the results of UV spectroscopy.

\section{Conclusions}

The effect of water/alcohol solutions on the thiourea thione-thiol isomerism was studied by Raman and UV spectroscopies. Using UV spectroscopy, it was shown that the thione form amount is increased in the water-methanol-ethanol-propanol-isopropyl alcohol row. In the same row, the thiol form amount is increased with the addition of hydrochloric acid due to the easier protonation of thiourea in water without acid and in alcohols upon acid addition. It was shown that Raman spectroscopy can be used to determine the thione form of thiourea accounting for $-\mathrm{C}=\mathrm{S}$ group.

\section{References}

1 Shakeel A. Thiourea derivatives in drug design and medicinal chemistry: A short review / A. Shakeel, A. Altaf, A. Qureshi, A. Badshah // Journal of Drug Design and Medicinal Chemistry. - 2016. - Vol. 2, No. 1. - P. 10-20. DOI: 10.11648/j.jddmc.20160201.12

2 Никулина А.Е. 4,5-дигидроксиимидазолидин-2-тион как ингибитор кислотной коррозии стали в соляно-кислых водных средах // А.Е. Никулина, Л.Е. Каличкина, Г.В. Лямина, О.В. Водянкина, В.С. Мальков // Коррозия: материалы и защита. - 2017. — № 7. - P. 18-22.

3 Vonlanthen M. Thiourea-based fluorescent chemosensors for aqueous metal ion detection and cellular imaging / M. Vonlanthen, C.M. Connelly, A. Linden, N.S. Finney // The Journal of Organic Chemistry — 2014. — Vol. 79, No. 20. — P. 6054-6060. DOI:10.1021/jo500710g

4 Singh M. The Synthetic Challenge of Thioglycolurils / M. Singh., G. Parvari, M. Botoshansky, E. Keinan, O. Reany // Eur. J. Org. Chem. — 2014. — Vol. 5, No. 2. - P. 933-940. DOI: 10.1002/ejoc.201301672

5 Schiessl W. Experimental and theoretical approaches to the protonation of thiourea: a convenient nucleophile in coordination chemistry / W.S chiessl, N. Summa, C. Webera, S. Gubo, C. Dücker-Benfera, R. Puchta, N. Eikema Hommes, R. Eldika // Zeitschrift für anorganische und allgemeine Chemie. — 2005. - Vol. 116, No. 631. - P. 2812-2819 DOI: 10.1002/zaac.200500157

6 Witanowski M. Nitrogen NMR shieldings of thiourea systems as a function of solvent polarity and hydrogen bond effects/ M. Witanowskia, Z. Biedrzyckaa, W. Sicinskaa, G.A. Webb// Journal of Molecular Structure — 2000. — Vol. 516, No. 2-3. P. 107-112.DOI: 10.1016/S0022-2860(99)00202-1

7 Pang S. Solvent-dependent dynamics of hydrogen bonding structure 5-(methylthio)-1,3,4-thiadiazole-2(3H)-thione as determined by Raman spectroscopy and theoretical calculation / S. Pang, Y. Zhao, X. Liu, J. Xue, X. Zheng // Spectrochimica Acta Part A: Molecular and Biomolecular Spectroscopy. — 2017. — Vol. 171. — P. 470-477. DOI: 10.1016/j.saa.2016.08.023

8 Dimova V. UV spectrophotometric determination of pK's of 1,2,4-triazoline-3-thiones in sodium hydroxide solutions / V. Dimova, I. Jordanov, L. Dimitrov // Journal of the Chilean Chemical Society. — 2016. — Vol. 61, No. 3. - P. 3071-3075. DOI: $10.4067 /$ S0717-97072016000300013

9 Hosoya H. Ultraviolet Absorption Spectra of Aqueous Solutions and Single Crystals of Thioacetamide and Thiourea / H. Hosoya, J. Tanaka, S. Nagakura // Bulletin of the Chemical Society of Japan. - 1959. — Vol. 33, No. 6. - P. 850-860. DOI: $10.1246 /$ bcsj. 33.850

10 Ragamathunnisa M. Spectroscopic study on Thiourea and Thiosemicarbazide in Non-aqueous media // M. Ragamathunnisa, E.J. Vasantha Rani, R. Padmavathy, N. Radha // Journal of Applied Physics. — 2013. — Vol. 4, No. 1. — P. 5-8.

11 Brennan N. Structural studies of thallium(I)-thiourea complexes / N. Brennan //Copyright by University of Pretoria. — 2005. P. $88-108$.

12 Zhang H. Resonance Raman spectroscopic and theoretical study of geometry distortion of thiourea in $2^{1} \mathrm{~A}$ state / H. Zhang, Y. Zhao, X. Zheng // Chin. J. Chem. Phys. - 2012. — Vol. 25, No. 1. - P. 1-10. DOI: 10.1088/1674-0068/25/01/1-10 


\title{
Л.Е. Каличкина, А.А. Бакибаев, В.С. Мальков \\ Су-спирт ерітінділерінде тиомочевинаның тион-тиолды таутомериясын спектрлік зерттеу
}

\begin{abstract}
Мақалада КШ (комбинациялық шашырау) және УК спектроскопия әдістерімен тиомочевинаның тионтиолды таутомериясының тепе-теңдігі зерттелген. Тион-тиолды изомерия тиомочевина мен басқа да органикалық қосылыстар арасындағы реакцияның барысы мен бағытына әсер етеді. Тион-тиолды изомерияны зерттеу суда және су-спирт ерітінділерінде жүргізілді, спирт ретінде метанол, этанол, пропанол-1, пропанол-2 алынды. Тұз қышқылы суда және су спирт ерітінділерінде тиомочевинаны протондау үшін пайдаланылды. УК-спектроскопия судағы және су-спирт ерітінділеріндегі таутомерлердің қатынасын 236 және 200 нм кезінде сіңіру жолақтарының қарқындылығының қатынасы ретінде орнатуға мүмкіндік берді. Су-метанол-этанол-пропанол-изопропил спирті қатарында тиомочевинаның тиол формасы құрамының артуы және тион формасының азаюы байқалады. Суда немесе су-спирт ерітінділерінде тиомочевинадан тұратын ерітінділерге тұз қышқылын қосу тиомочевинаның тион формасының ұлғаюына және тиол формасының азаюына әкеледі. КШ спектроскопия әдісін $-\mathrm{C}=\mathrm{S}$ топ бойынша тиомочевинаның тион формасын анықтау үшін пайдаланылады. S-H байланысы сіңіру жолақтарының спирттердің сіңіру жолақтарымен жабылуына байланысты тиомочевинаның тиол формасын комбинациялық шашырау спектроскопиясы арқылы анықтау қиын.
\end{abstract}

Кілm сөздер: тиомочевина, тион-тиолды таутомерия, КШ-спектроскопия, УК-спектроскопия, автопротолиз тұрақтысы, тиомочевинаны протондау, еріткіш әсері.

\author{
Л.Е. Каличкина, А.А. Бакибаев, В.С. Мальков
}

\section{Спектральное исследование тион-тиольной таутомерии тиомочевины в водно-спиртовых растворах}

\begin{abstract}
В статье исследовано равновесие тион-тиольной таутомерии тиомочевины методами КР- и УФ-спектроскопии. Тион-тиольная изомерия влияет на ход и направление реакции между тиомочевиной и другими органическими соединениями. Исследование тион-тиольной изомерии проводили в воде и водно-спиртовых растворах, в качестве спиртов были выбраны: метанол, этанол, пропанол-1, пропанол-2. Соляную кислоту использовали для протонирования тиомочевины в воде и водных спиртовых растворах. УФ-спектроскопия позволила установить соотношение таутомеров в воде и водноспиртовых растворах как отношение интенсивностей полос поглощения при 236 и 200 нм. В ряду «вода - метанол - этанол - пропанол - изопропиловый спирт» наблюдаются увеличение содержания тиольной формы и уменьшение тионной формы тиомочевины. Добавление соляной кислоты к растворам, состоящим из тиомочевины в воде или в водно-спиртовых растворах, приводит к увеличению содержания тионной формы и уменьшению содержания тиольной формы тиомочевины. Метод КР-спектроскопии по $-\mathrm{C}=\mathrm{S}$ группе может быть использован для определения тионной формы тиомочевины. Тиольную форму тиомочевины трудно определить с помощью спектроскопии комбинационного рассеяния из-за перекрывания полосы поглощения связи S-H с полосами поглощения спиртов.
\end{abstract}

Ключевые слова: тиомочевина, тион-тиольная таутомерия, КР-спектроскопия, УФ-спектроскопия, константа автопротолиза, протонизация тиомочевины, эффекты растворителя.

\section{References}

1 Shakeel, A., Altaf, A., Qureshi, A., \& Badshah, A. (2016). Thiourea derivatives in drug design and medicinal chemistry: A short review. Journal of Drug Design and Medicinal Chemistry, 2(1), 10-20.

2 Nikulina, A.E., Kalichkina, L.E., Lyamina, G.V., Vodyankina, O.V., Malkov, V.S. (2017). 4,5-Dihidroksiimidazolidin-2-tion kak inhibitor korrozii stali v soliano-kislykh vodnykh sredakh [4,5-dihydroxyimidazolidin-2-thione as an acid corrosion inhibitor for steel in water-hydrochloric acid solutions]. Korroziia: Materialy i zashchita. - Corrosion: materials and protection. 7, 18-22 [in Russian].

3 Vonlanthen, M., Connelly, C.M., Linden, A., \& Finney, N.S. (2014). Thiourea-based fluorescent chemosensors for aqueous metal ion detection and cellular imaging. The Journal of Organic Chemistry, 79(20), 6054-6060.

4 Singh, M., Parvari, G., Botoshansky, M., Keinan, E., \& Reany, O. (2014). The Synthetic Challenge of Thioglycolurils. Eur. J. Org. Chem., 5(2), 933-940.

5 Schiessl, W., Summa, N., Webera, C., Gubo, S., Dücker-Benfera, C., \& Puchta, R., et. al. (2005). Experimental and theoretical approaches to the protonation of thiourea: a convenient nucleophile in coordination chemistry. Zeitschrift für anorganische und allgemeine Chemie, 116(631), 2812-2819. 
6 Witanowskia, M., Biedrzyckaa, Z., Sicinskaa, W, \& Webb, G.A. (2000). Nitrogen NMR shieldings of thiourea systems as a function of solvent polarity and hydrogen bond effects. Journal of Molecular Structure, 516(2), 107-112.

7 Pang, S., Zhao, Y., Liu, X., Xue, J., \& Zheng, X. (2017). Solvent-dependent dynamics of hydrogen bonding structure 5-(methylthio)-1,3,4-thiadiazole-2(3H)-thione as determined by Raman spectroscopy and theoretical calculation. Spectrochimica Acta Part A: Molecular and Biomolecular Spectroscopy, 171, 470-477.

8 Dimova, V., Jordanov, I., Dimitrov, L. UV spectrophotometric determination of pK's of 1,2,4-triazoline-3-thiones in sodium hydroxide solutions (2016). Journal of the Chilean Chemical Society, 61(3), 3071-3075.

9 Hosoya, H., Tanaka, J., Nagakura, S. (1959). Ultraviolet absorption spectra of aqueous solutions and single crystals of thioacetamide and thiourea. Bulletin of the Chemical Society of Japan, 33(6), 850-860.

10 Ragamathunnisa, M., Vasantha Rani, E.J., Padmavathy, R., \& Radha, N. (2013). Spectroscopic study on thiourea and thiosemicarbazide in non-aqueous media. Journal of Applied Physics, 4(1), 5-8.

11 Brennan, N.F. (2005). Structural studies of thallium (I) - thiourea complexes. Magister Scientiae. Pretoria.

12 Zhang, H., Zhao, Y., Zheng, X. (2012). Resonance Raman spectroscopic and theoretical study of geometry distortion of thiourea in $2{ }^{\mathrm{A}}$ state. Chin. J. Chem. Phys., 25(1), 1-10. 